\title{
Purulent pericarditis in children: an analysis of 28 cases
}

\author{
E. K. WEIR ${ }^{1}$ AND H. S. JOFFE \\ From the Cardiology Unit, Red Cross War Memorial Children's Hospital, Cape Town, South Africa
}

Weir, E. K., and Joffe, H. S. (1977). Thorax, 32, 438-443. Purulent pericarditis in children: an analysis of 28 cases. Bacterial pericarditis was diagnosed in 28 children under the age of 13 years during a five-year period at one hospital. The diagnosis was established clinically in 26 cases; in two the condition was first recognised at necropsy. Staphylococcus aureus was isolated in 22 patients, including all 12 with associated osteitis. The other principal primary condition was pneumonia.

While 11 patients were treated with antibiotics only, 13 required one or more pericardial aspirations. Acute constrictive pericarditis occurred in two children, both of whom survived pericardiectomy. Of the 26 children with a clinical diagnosis of bacterial pericarditis, eight died in hospital $(31 \%)$. The pericarditis probably caused death in two cases and was contributory in six.

Septic pericarditis tends to occur in children who are already ill because of other foci of bacterial infection and may easily be overlooked, especially in infants. The large numbers reported reflect a high incidence of osteitis in this community. Electrocardiographic and radiological changes are almost always demonstrable, but these are not diagnostic. Antibiotic therapy is imperative and drainage of the pericardium is usually indicated. Bacterial pericarditis is associated with a high mortality. However, while early recognition and treatment is important, death is more often due to the gereral septicaemia than to pericardial tamponade. In this respect the pericarditis is one indication of the severity of the systemic illness.

The incidence of acute bacterial pericarditis has decreased steadily during the last 30 years (Boyle et al., 1961; Evans, 1961; Benzing and Kaplan, 1963) because improved social conditions and the advent of antibiotics have reduced the occurrence of predisposing infections such as pneumonia and osteitis. The current position in the United States is well illustrated by a review of 25 children with acute bacterial pericarditis seen in Washington DC over a period of 12 years; 'the largest published series from a single institution' (Rubin and Moellering, 1975). The character of the disease has altered and, in addition to being less common, it is now seen relatively more often in patients whose ability to combat infections is impaired (Rubin and Moellering, 1975; Okoroma et al., 1975). Consequently the mortality remains considerable. In contrast, the incidence of septic conditions such as osteitis is still high in the

${ }^{1}$ Present address: Department of Cardiology, Wentworth Hospital, P. B. Jacobs, Natal, 4026, South Africa population served by our hospital. The socioeconomic conditions have been described before (Schrire, 1959; Schrire, 1967). During the five years from 1971 to 1975,28 children have been found to have acute bacterial pericarditis. The data presented in this paper allow comparison of the clinical features and management of such patients today with similar cases presenting over 20 years ago.

\section{Patient material}

The records of all children admitted to Red Cross War Memorial Children's Hospital from 1971 to 1975 with a diagnosis of acute bacterial peri- $\mathbb{D}$ carditis were reviewed (26 patients). In addition ? the necropsy register was examined in order to include patients in whom the diagnosis was not made during life (two patients). The clinical diagnosis was considered to be proven on the $\stackrel{D}{\circ}$ appearance of the pericardial fluid (obtained by 


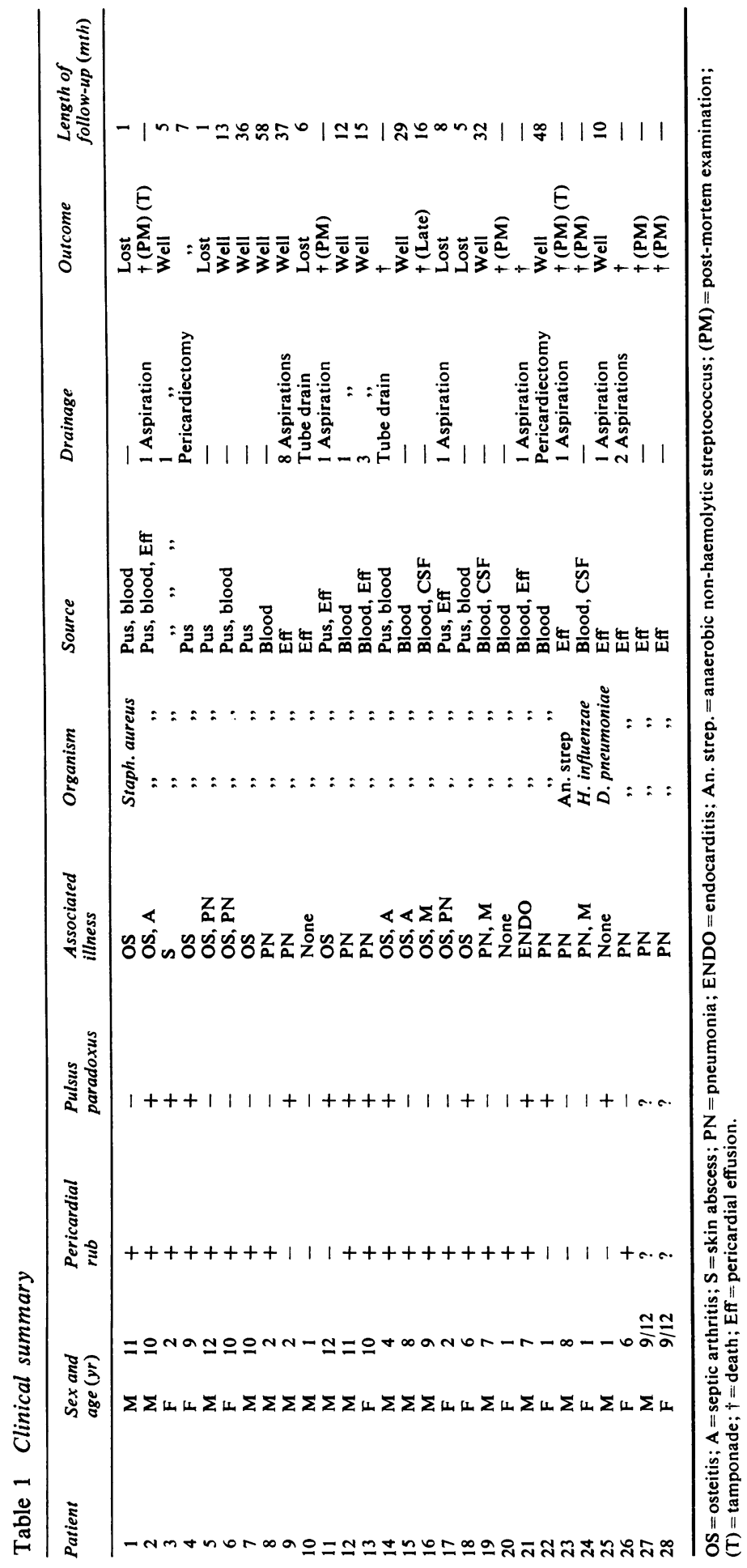


aspiration, at operation, or at necropsy) together with a positive bacterial culture from the pericardial fluid, blood, or pus from associated osteitis (18 patients). Alternatively, the presence of a persistent pericardial friction rub associated with repolarisation changes in the electrocardiogram and an enlarged heart shadow in the radiograph, combined with a positive culture, was accepted as diagnostic (10 patients). In many cases the same organism was isolated from more than one source. Patients who developed bacterial pericarditis after operation were not included.

\section{CLINICAL DATA}

The clinical features of those patients recognised as having bacterial pericarditis are shown in Table 1 (Nos. 1-26). The two infants in whom the presence of pericarditis was diagnosed at necropsy only are numbered 27 and 28 . These were both aged 9 months and were the youngest in the series. The oldest child was 12 years. The mean age was $6 \pm 1$ years. Twenty-five of the children were from the Cape coloured community, two were black, and one was white. There were 17 boys and 11 girls.

Twenty-three of the patients diagnosed during life had either a pericardial rub (11) or pulsus paradoxus (4) or both (8). Limitation of right heart filling, as shown by hepatomegaly and peripheral oedema, was noted in 18. The electrocardiogram was available in all but one case and invariably demonstrated sinus rhythm with a normal PR interval (mean 0.13 second) and a normal QRS axis (range $10-90^{\circ}$ ). The repolarisation phase was normal in only two tracings; the rest had widespread ST segment elevation (6), T wave inversion (15), or both (2). Chest radiographs were obtained in 24 patients and showed some degree of cardiomegaly in all but one.

\section{BACTERIOLOGY}

A focus of bacterial infection elsewhere in the body was identified in 25 of the 28 children. The responsible organisms are listed in Table 2 . The illnesses most commonly associated were pneu-
Table 2 Bacteriology and outcome

\begin{tabular}{lll}
\hline & $\begin{array}{l}\text { Total No } \\
\text { of patients }\end{array}$ & $\begin{array}{l}\text { Died in } \\
\text { hospital }\end{array}$ \\
\hline Staph. aureus & 22 & $5(23 \%)$ \\
D. pneumoniae & 4 & $3(75 \%)$ \\
H. influenzae & 1 & 1 \\
An. strep. & 1 & 1 \\
\hline
\end{tabular}

Includes the two patients diagnosed at necropsy (both $D$. pneumoniae). An. strep $=$ anaerobic non-haemolytic streptococcus.

monia (14) and osteitis (12) (Table 1). During the five years under review 776 patients were admitted to the hospital with osteitis. Thus the incidence of bacterial pericarditis detected in those with osteitis was $1.5 \%$ and Staphylococcus aureus was responsible in all cases.

\section{TREATMENT}

All patients in whom a clinical diagnosis of bacterial pericarditis was made were treated with antibiotics (Table 3). Cloxacillin was used in the 22 patients from whom Staphylococcus aureus was isolated. Fucidin was added in 11 of these cases but did not appear to alter the mortality or course of the disease. Other antibiotics, in particular penicillin, were frequently used but no evidence was obtained of the superiority of any one antibiotic regime. Needle aspiration of fluid from the pericardium was performed on one or $\overrightarrow{\vec{P}}$ more occasions in 13 patients $(50 \%)$. In two of these (Nos. 10 and 14) reaccumulation of the fluid after several aspirations led to surgical drainage of the pericardium. Two children (Nos. 4 and 22) did not require aspiration in the acute stage of their illness but developed constrictive pericarditis $\underset{\times}{\otimes}$ within two months of admission. In one of them an ejection systolic murmur was heard at the 3 . pulmonary area. A $60 \mathrm{mmHg}$ gradient across the $\delta$ right ventricular outflow tract was demonstrated at cardiac catheterisation. Right ventricular 0 cineangiography showed infundibular stenosis (Figure). At operation a tight fibrous band was found over the outflow of the right ventricle. Both patients made a good recovery after peri- $\sigma$ cardiectomy.

Table 3 Treatment and outcome

\begin{tabular}{|c|c|c|c|c|c|}
\hline \multirow[b]{2}{*}{ Treatment } & \multicolumn{3}{|l|}{ Hospital } & \multicolumn{2}{|c|}{ Follow-up } \\
\hline & No of patients & Died & Discharged & Lost & Alive and well \\
\hline $\begin{array}{l}\text { Antibiotics only } \\
\text { Antibiotics and aspiration } \\
\text { Pericardiectomy } \\
\text { All groups }\end{array}$ & $\begin{array}{r}11 \\
13 \\
2 \\
26\end{array}$ & $\begin{array}{l}2 \\
6 \\
0 \\
8\end{array}$ & $\begin{array}{r}9 \\
7 \\
2 \\
18\end{array}$ & $\begin{array}{l}3+1 \\
2 \\
0 \\
6\end{array}$ & $\begin{array}{r}5 \\
5 \\
2 \\
12\end{array}$ \\
\hline
\end{tabular}

Analyses only the 26 patients diagnosed during life.

The +1 in the 'antibiotics only' group represents the only late death. 


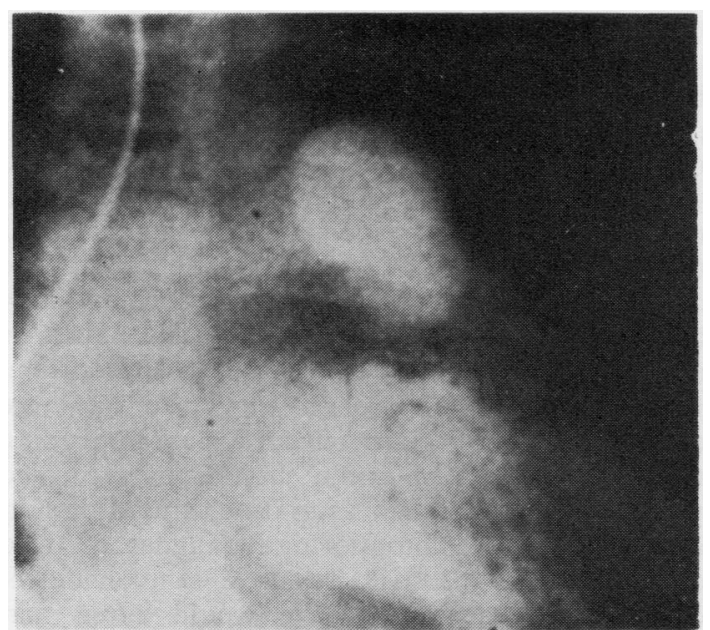

Figure Right ventricular cineangiogram. The fibrous band lying between the body of the ventricle and the main pulmonary artery causes infundibular stenosis.

\section{COURSE}

Ten of the 28 patients died in hospital. Tamponade caused the death of two in whom bacterial pericarditis had been diagnosed clinically. Both had undergone pericardial aspiration with initial benefit but subsequently developed tamponade which was undetected. Tamponade was not responsible for the deaths of the two infants first diagnosed at necropsy. While both had small purulent pericardial effusions (Diplococcus pneumoniae), they probably succumbed to pneumonia and septicaemia. Similarly, bacterial pericarditis was not thought to be the direct cause of death in the remaining six patients but was probably a contributory factor. Although more deaths occurred in patients undergoing pericardial aspiration than in those treated with antibiotics alone (Table 3), this difference is not statistically significant. Furthermore, the children requiring aspiration tended to be more ill. The hospital mortality was $36 \%$ in the total group and $31 \%$ in those recognised during life. The mean period in hospital before death was $1.5 \pm 0.5$ weeks. The mean period between admission and discharge for the 18 patients successfully treated was $8 \pm 1$ weeks.

Of the 18 patients who left hospital, five have been lost to follow-up. They were all well when last seen $4 \pm 1$ months after discharge. One patient died of unrelated causes 16 months after discharge. The remaining 12 children have been followed for $25 \pm 5$ months and have no signs to suggest the development of constrictive pericarditis.

\section{Discussion}

The reported criteria for the diagnosis of septic pericarditis are variable so that comparison of data from different institutions is difficult. Our criteria were, however, very similar to those used in two earlier series (Benzing and Kaplan, 1963; Van Reken et al., 1974). We required demonstration of pericardial fluid or else convincing clinical evidence of pericarditis (a persistent pericardial friction rub together with electrocardiographic and radiological changes). In addition, a positive culture from the pericardial fluid, blood or bone was essential. Some workers feel that the diagnos is can be made on the basis of purulent pericardial fluid alone, in the absence of a positive culture (Okoroma et al., 1975). This situation is becoming more common as antibiotics are frequently used before the patient's admission.

While we attempted to exclude false positive diagnoses by our criteria, it is probable that some patients with bacterial pericarditis are not included. For instance, patient 24 had marked cardiomegaly on the chest radiograph and widespread $\mathbf{T}$ wave inversion on the electrocardiograph, but a friction rub was not detected. Although she was thought to have pericarditis, she would not have been included in this series but for the fact that she died as a result of meningitis and pneumonia and was found to have purulent pericarditis at post-mortem examination. Such cases suggest that the incidence of septic pericarditis may be higher than is indicated by clinical reports.

The clinical diagnosis of bacterial pericarditis may be difficult. The two youngest patients in this series (both 9 months old) were only diagnosed at necropsy. The condition was not recognised during life in three of seven infants in one report (Gersony and McCracken, 1967), in five of 11 adults in another (Boyle et al., 1961), and in eight of 26 patients of all ages in a third (Rubin and Moellering, 1975). Obviously, the incidence of pericarditis recognised only after death will depend on the frequency of post-mortem examinations. The possibility of bacterial pericarditis should be considered in any sick patient with a primary septic focus, especially if their immune responses are impaired.

Bacterial pericarditis may occur in the absence of any demonstrable septic condition elsewhere in the body. Fifty infants with purulent pericarditis were described in the literature up to 1967 (Gersony and McCracken, 1967), of whom seven had no other septic lesion. In our series three patients appeared to have isolated bacterial peri- 
carditis. All 37 children reported in two recent papers were shown to have sepsis elsewhere (Van Reken et al., 1974; Okoroma et al., 1975).

Because of poor socioeconomic conditions osteitis is an all too common condition in this area. Pericarditis was associated with osteitis in $43 \%$ of our patients. This is in contrast to an association of $6 \%$ in 52 children described in four articles covering the last 25 years in the United States (Benzing and Kaplan, 1963; Gersony and McCracken, 1967; Van Reken et al., 1974; Okoroma et al., 1975). Staphylococcus aureus was isolated in the great majority of cases in our series, largely as a reflection of the high incidence of osteitis. This organism also causes much of the pericarditis seen in other regions, but it is then more commonly related to pneumonia or skin sepsis (Gersony and McCracken, 1967; Van Reken et al., 1974).

D. pneumoniae was a common cause of pericarditis until the advent of penicillin (Boyle et al., 1961). However, between 1945 and 1973 only 15 further cases were reported (Kauffman et al., 1973). In the four articles concerning children mentioned above, $D$. pneumoniae was responsible for only three of the 44 positive cultures. In this series $D$. pneumoniae was cultured from the pericardial effusions of four patients, of whom three died. Thus, although it has become less frequent, pneumococcal pericarditis does still occur and carries a high mortality. Anaerobic streptococci have been reported to cause pericarditis in only two previous cases (Tahernia and Sharif, 1970).

The morbidity and mortality of patients with bacterial pericarditis depends not only on the course of the pericarditis but is often determined by the 'collateral foci of disease' (Adams and Polderman, 1941). Thus caution is necessary in assessing the mortality figures shown in Table 4 . It appears that the mortality rate of children who are admitted to major centres with bacterial pericarditis or who develop the condition in hospital is about $40 \%$.

The variety of the associated diseases and their responsible organisms, combined with the com-

Table 4 Mortality in bacterial pericarditis during childhood

\begin{tabular}{lllll}
\hline Author & $\begin{array}{l}\text { Period of } \\
\text { study }\end{array}$ & $\begin{array}{l}\text { Age } \\
(y r)\end{array}$ & $\begin{array}{l}\text { Mortality } \\
\%\end{array}$ & $\begin{array}{l}\text { No of } \\
\text { patients }\end{array}$ \\
\hline Benzing and Kaplan & $1952-62$ & $<16$ & 12 & 8 \\
Gersony et al. & $1956-66$ & $<2$ & 43 & 7 \\
Van Reken et al. & $1958-73$ & $<15$ & 58 & 12 \\
Okoroma et al. & $1962-73$ & $<15$ & 52 & 25 \\
This series & $1971-75$ & $<13$ & 36 & 28 \\
\hline
\end{tabular}

parative rarity of bacterial pericarditis, makes a controlled trial of therapy very difficult. Antibiotics are obviously indicated, but drainage of the pericardium does not appear to be essential for recovery in all cases. Of the 11 patients treated with antibiotics alone, nine were discharged, and tamponade was not responsible for the deaths of the remaining two. If there is doubt about the diagnosis of an effusion echocardiography may help. If an effusion is present, but its nature is uncertain, pericardial aspiration is appropriate If there is evidence of a moderate or large effusion, or there is any suggestion of impending tamponade, then aspiration should be performed without delay. Whether aspiration is used or not, a high standard of monitoring is mandatory. Two of our patients died as a result of tamponade recurring after aspiration. We would agree that 'pericardiostomy is advisable in those patients in whom recurrent cardiac tamponade develops in spite of repeated aspirations and in those in whom the fluid is thick or aspirated with difficulty' (Benzing and Kaplan, 1963). Different surgical approaches to drainage have recently been reviewed (Cameron, 1975). However, pericardiostomy is not without complications (Boyle et al., 1961), and the statement made in 1941 that 'needle aspiration almost uniformly fails to save the patient' (Adams and Polderman, 1941) is no longer true. The majority of patients can be managed on antibiotics alone or by antibiotics and aspiration.

Acute constriction, within a few months of the onset of the illness and without a period of remission, is well recognised (Boyle et al., 1961; Okoroma et al., 1975) even in infancy (Caird $e t$ al., 1973; Van Reken et al., 1974). We considered that the lack of pericardial drainage might have contributed to the acute constriction which developed in two of our patients. However, a baby ( 8 months old) has been reported in whom constriction occurred despite initial pericardiocentesis and subsequent drainage through a pericardia window (Van Reken et al., 1974). Thus patients should be carefully observed for at least two months after the onset of bacterial pericarditis in order to detect possible constriction. Our patient with a fibrous band across the right ventricular outflow tract causing infundibular stenosis is very similar to a case recently reported (Chesler et al. 1976). Chronic constriction following septic pericarditis is relatively uncommon (Boyle et al. 1961) and during the period of follow-up no child in this series has developed signs of constriction.

We are very grateful to Professor E. Chesler for his 
critical review of the paper, to Miss Karen Leahy and Mrs. Pamela Peters for help in the preparation of the manuscript, and to Professor S. Cywes and Dr. A. Katz, of the Department of Surgery, for their co-operation. The study was supported by the Clyde Children's Heart Fund. We thank the Medical Superintendent of Red Cross War Memorial Children's Hospital for permission to publish.

\section{References}

Adams, R., and Polderman, H. (1941). Suppurative pericarditis. New England Journal of Medicine, 225, 897-902.

Benzing, G., and Kaplan, S. (1963). Purulent pericarditis. American Journal of Diseases of Children, 106, 289-294.

Boyle, J. D., Pearce, M. L., and Guze, L. B. (1961). Purulent pericarditis: review of literature and report of eleven cases. Medicine, 40, 119-144.

Caird, R., Conway, N., and McMillan, I. K. R. (1973). Purulent pericarditis followed by early constriction in young children. British Heart Journal, 35, 201203.

Cameron, E. W. J. (1975). Surgical management of staphylococcal pericarditis. Thorax, 30, 678-681.

Chesler, E., Mitha, A. S., Matisonn, R. E., and Rogers, M. N. A. (1976). Subpulmonic stenosis as a result of noncalcific constrictive pericarditis. Chest, 69, 425427.

Evans, E. (1961). Introduction to a symposium on pericarditis. American Journal of Cardiology, 7, $1-6$.
Gersony, W. M., and McCracken, G. H., Jr. (1967). Purulent pericarditis in infancy. Pediatrics, 40, 224-232.

Kauffman, C. A., Watanakunakorn, C., and Phair, J. P. (1973). Purulent pneumococcal pericarditis. American Journal of Medicine, 54, 743-750.

Okoroma, E. O., Perry, L. W., and Scott, L. P. (1975). Acute bacterial pericarditis in children: report of 25 cases. American Heart Journal, 90, 709-713.

Rubin, R. H., and Moellering, R. C., Jr. (1975). Clinical, microbiologic and therapeutic aspects of purulent pericarditis. American Journal of Medicine, 59, 68-78.

Schrire, V. (1959). Experience with pericarditis at Groote Schuur Hospital, Cape Town. South A frican Medical Journal, 33, 810-817.

Schrire, V. (1967). Pericarditis (with particular reference to tuberculosis pericarditis). Australasian Annals of Medicine, 16, 41-51.

Tahernia, A. C., and Sharif, H. (1970). Purulent pericarditis in childhood. Two examples, one due to anaerobic streptococcus. Clinical Pediatrics, 9, 499-502.

Van Reken, D., Strauss, A., Hernandez, A., and Feigin, R. D. (1974). Infectious pericarditis in children. Journal of Pediatrics, 85, 165-169.

Requests for reprints to: Dr. H. S. Joffe, Cardiology Unit, Red Cross War Memorial Children's Hospital, Cape Town, South Africa. 